\title{
Analysis of the impact of the level of knowledge on the decision to vaccinate
}

\section{Analiza wpływu poziomu wiedzy na temat szczepień ochronnych na decyzje o wykonywaniu szczepień ochronnych}

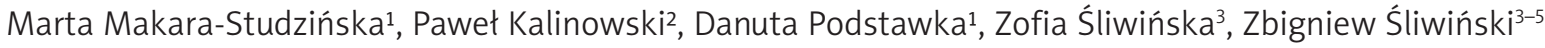 \\ 'Department of Applied Psychology, Medical University of Lublin, Lublin, Poland \\ Head of the Department: Prof. Marta Makara-Studzińska MD, PhD \\ 2Laboratory Epidemilogy, Medical University of Lublin, Lublin, Poland \\ Head of the Department: Paweł Kalinowski MD, PhD \\ ${ }^{3}$ Physiotherapy Centre in Zgorzelec, Multidisciplinary Team of Public Welfare Health in Zgorzelec, Poland \\ Head of the Department: Prof. JKU Zbigniew Śliwiński MD, PhD \\ ${ }^{4}$ Manual Medicine Department, Institute of Physiotherapy, Faculty of Health Sciences, Jan Kochanowski University, Kielce, Poland \\ Head of the Department: Prof. JKU Zbigniew Śliwiński \\ ${ }^{5}$ Faculty of Health Sciences, Medical University of Wroclaw, Wroclaw, Poland \\ Head of the Department: Prof. MUW Joanna Rosińczuk PhD
}

Key words: vaccinations, infectious diseases, prevention.

Słowa kluczowe: szczepienia ochronne, choroby zakaźne, profilaktyka.

\begin{abstract}
Introduction: Infectious diseases are still a significant medical and social problem in the contemporary world. The most effective and at the same time the least expensive way to become protected against infectious diseases is vaccinations. Appropriate education of the society referring to the prevention of infectious diseases such as measles, diphtheria, or pertussis can contribute to changing the attitudes of many parents to mandatory and recommended vaccinations.

Aim of the research: The analysis of the impact of the level of knowledge on making decisions about administering preventive vaccinations.

Material and methods: The study included 370 participants (308 women and 62 men). They were students of Lublin universities and young parents living in the Lublin voivodeship. The research tool was an author-made questionnaire consisting of 20 closed questions. For the statistical analysis of research results the methods of descriptive statistics, the $\chi^{2}$ test, and Cramer's V correlation coefficient were used.

Results: As many as $98 \%$ of the respondents exhibiting a higher level of knowledge declared future regular vaccinations of their children in accordance with the official recommendations. Among people with a low level of knowledge, only $45 \%$ declared such regularity in their children's vaccination. As many as $62 \%$ of the respondents who lacked knowledge on vaccinations failed to have voluntary vaccinations administered. In comparison, among those with high level of knowledge, $50 \%$ never had recommended vaccinations administered.

Conclusions: The level of knowledge has a significant impact on the decisions on administering preventive vaccinations in the studied population. Respondents who had a higher level of knowledge more frequently declared administering vaccinations regularly, both to themselves and their children.
\end{abstract}

\section{Streszczenie}

Wprowadzenie: Choroby zakaźne są nadal istotnym problemem zarówno medycznym, jak i społecznym we współczesnym świecie. Najskuteczniejszą i jednocześnie najtańszą metodą zabezpieczenia się przed chorobami zakaźnymi są szczepienia ochronne. Odpowiednia edukacja społeczeństwa w zakresie zapobiegania chorobom zakaźnym, takim jak odra, błonica, krztusiec, może się przyczynić do zmiany postawy wielu rodziców wobec szczepień obowiązkowych oraz zalecanych. Cel pracy: Analiza wpływu poziomu wiedzy na decyzje o wykonywaniu szczepień ochronnych.

Materiał i metody: Badaniem objęto 370 osób (308 kobiet i 62 mężczyzn), studentów lubelskich uczelni oraz młodych rodziców zamieszkujących województwo lubelskie. Narzędziem badawczym była autorska ankieta wywiadu zawierająca 20 pytań zamkniętych. Do analizy statystycznej wyników badania zastosowano metody statystyki opisowej oraz test $\chi^{2}$ i współczynnik korelacji V Cramera. 
Wyniki: Spośród respondentów o wyższym poziomie wiedzy aż 98\% deklarowało regularne wykonywanie szczepień u swoich dzieci, zgodnie z kalendarzem szczepień, w przyszłości. Tylko 45\% badanych wśród osób o niskim poziomie wiedzy deklarowało regularność szczepień u swoich dzieci. Aż 62\% respondentów nieposiadających wiedzy na temat szczepień ochronnych nigdy nie wykonało u siebie nieobowiązkowych szczepień. W grupie osób mających dużą wiedzę 50\% nigdy nie wykonało szczepień zalecanych.

Wnioski: Poziom wiedzy istotnie wpływa na decyzję o wykonywaniu szczepień ochronnych w badanej populacji. Osoby o wyższym poziomie wiedzy znacznie częściej deklarowały regularne wykonywanie szczepień ochronnych u swoich dzieci.

\section{Introduction}

Contagious diseases are still a significant issue in the modern medical - as well as social - world. One of the most effective methods of protection against contagious diseases is vaccination, as an active prophylaxis of infectious diseases. This method is thought to be the most efficacious and the cheapest measure to globally secure the health of the population. Thanks to obligatory preventive vaccinations the incidence and mortality rate of several infectious diseases, such as diphtheria, tetanus, and hepatitis type B [1], have been reduced.

In Poland vaccination is a common and mass procedure performed in accordance with the calendar/ schedule of obligatory vaccinations. Vaccination may also be carried out in an individual manner considering recommended vaccinations. The realisation of prophylactic vaccinations in Poland has achieved a high level.

However, the parents' shortage of knowledge regarding diseases whose incidence has been reduced due to vaccinations is worrying. There are faulty opinions, according to which vaccination is not necessary since the incidence of certain contagious diseases is very low. English research confirms this relation: there tend to be fewer mothers who think that such infectious diseases as poliomyelitis or pertussis (whooping cough) may bring about serious consequences should a child be affected [2].

There seem to be more and more anti vaccination groups, which, to promote their fallacious theories, use the lack of relevant knowledge among parents who know little about active immunisation, possible post vaccination complications, or the dangers stemming from a given disease [3-5].

Numerous studies show that a large number of parents do not have the necessary knowledge about the dangers resulting from infectious diseases, or about the preventive vaccinations to which their children are subjected according to the vaccinations schedule [1]. American researchers maintain that most persons think that disorders such as measles or pertussis will not occur since they are not occurring at present [2]. Erroneous conviction may cause a decrease of vaccination against these diseases, thus facilitating their new spread among the population. Also a lack of unbiased information about postvaccinal side effects delivered by medical personnel may generate among parents ideas of harmful effects caused by vaccinations, and thus enhance their fear of vaccination [6].

Therefore, proper education referring to prophylactic vaccinations is vital. The authority with which parents endow doctors should make a firm basis for re-shaping parental attitude toward vaccinations.

\section{Aim of the research}

The assessment of the impact of knowledge about vaccinations on the decision to perform obligatory and non-obligatory preventive vaccinations.

\section{Material and methods}

The study embraced 370 people (308 females and 62 males), students of Lublin colleges, as well as young parents living in Lublin Voivodeship. The test tool was an original questionnaire consisting of 20 closed questions. For the purpose of statistical analysis a descriptive statistical method was applied, using the $\chi^{2}$ testand Cramer's V correlation coefficient.

To assess the respondents' knowledge, the respondents were asked about possible effects of vaccinations, the efficacy of vaccinations, and postvaccinal effects that might be dangerous to children. The respondents were also asked about illnesses that can be caused by vaccinations. Each tested individual could maximally score 30 points. Persons who scored 26-30 points were classified as persons well knowledgeable about prophylactic vaccinations. Persons who scored 21-25 points were classified as satisfactorily knowledgeable about vaccinations. Persons who scored less than 20 points were classified as deficiently knowledgeable about vaccinations.

The satisfactorily knowledgeable group was the largest (46\%). Only $14 \%$ of the studied individuals were well knowledgeable about the subject. Almost $40 \%$ of the participants possessed little knowledge of vaccinations.

\section{Results}

A statistically significant relationship between the knowledge level and the studied subjects' decision on future vaccination of their children according to schedule was observed. About $98 \%$ of the well knowledgeable persons declared they would have their children regularly vaccinated in accordance with the schedule. Persons who turned out to be moderately knowledgeable also declared they would have their 
children regularly vaccinated. Those whose knowledge of vaccinations was small did not care much about vaccination, and $49 \%$ of them stated that they would have their children vaccinated, although they did not think it would be of importance (Table I).

The respondents were also asked whether they would have their children vaccinated if the presently obligatory vaccinations were non-obligatory. Also in this case a statistically significant relationship ( $p<0.001)$ between the knowledge level and willingness to have all vaccination done was observed. About $92 \%$ of highly knowledgeable persons were willing to have all the scheduled vaccinations administered to their children, even if they were non-obligatory. On the other hand, only approximately $28 \%$ of parents whose knowledge level was low wished to have all the recommended vaccinations administered. Most of these parents (63\%) said they would not have their children vaccinated if the procedure were non-obligatory (Table II).
The participants of the study were also asked if they would undergo non-obligatory vaccinations recommended by physicians and pharmacists, e.g. vaccinations against influenza. In this case the level of knowledge was of significance too $(p<0.001)$. Persons characterised by high and medium level of knowledge on vaccinations more often declared regularity of non-obligatory vaccinations. As for the persons whose knowledge level was low, $62 \%$ of them would never be non-obligatorily vaccinated (Table III).

The influence of the economic factor on the decision to vaccinate was also taken into consideration. The respondents were asked if they would be non-obligatorily vaccinated, e.g. against influenza, if the procedure were free of charge (refunded). There was a statistical relationship ( $p<0.001)$ : persons of higher knowledge level declared they would regularly be vaccinated in such a case. The refund would not change the decision among persons whose level of knowledge was low; just $14 \%$ of them would be regu-

Table I. Respondents' opinions about obligatory vaccinations of their children in the future (Will you have your children vaccinated according to the obligatory schedule?)

\begin{tabular}{|lccc|}
\hline Level of knowledge & $\begin{array}{c}\text { Yes, regularly according } \\
\text { to schedule [\%] }\end{array}$ & $\begin{array}{c}\text { Yes, but I do not think } \\
\text { it important [\%] }\end{array}$ & $\begin{array}{c}\text { Only when I am } \\
\text { coerced [\%] }\end{array}$ \\
Medium & 91.18 & 8.82 & 0 \\
Medium and low & 45.64 & 49.66 & 4.7 \\
High & 98.04 & 1.96 & 0 \\
\hline
\end{tabular}

$p<0.001$, V Cramer $=0.37$.

Table II. Respondents' opinions about obligatory vaccinations of their children if they were only recommended (If the presently obligatory vaccinations were non-obligatory, would you have your children vaccinated?)

\begin{tabular}{|lccc|}
\hline Level of knowledge & $\begin{array}{c}\text { Yes, all the recommended } \\
\text { vaccinations [\%] }\end{array}$ & $\begin{array}{c}\text { Not all the recommended } \\
\text { vaccinations [\%] }\end{array}$ & $\begin{array}{c}\text { Some of the recommended } \\
\text { [\%] }\end{array}$ \\
Medium & 82.35 & 16.47 & 1.18 \\
Medium and very low & 28.19 & 63.09 & 8.72 \\
High & 92.16 & 7.84 & 0 \\
\hline
\end{tabular}

$p<0.001, v$ Cramer $=0.40$.

Table III. Recommended vaccinations in respondents (Are you non-obligatorily vaccinated as recommended by physicians and pharmacists?)

\begin{tabular}{|lcccc|}
\hline Level of knowledge & $\begin{array}{c}\text { I vaccinate regularly } \\
\text { [\%] }\end{array}$ & $\begin{array}{c}\text { Often, but not } \\
\text { as often as } \\
\text { recommended [\%] }\end{array}$ & I was once [\%] & I never have [\%] \\
Medium & 5.29 & 44.12 & 15.29 & 35.29 \\
Low and very low & 0.67 & 10.07 & 26.85 & 62.42 \\
High & 3.92 & 23.53 & 21.57 & 50.98 \\
\hline
\end{tabular}

$p<0.001, v$ Cramer $=0.27$. 
larly non-obligatorily vaccinated. Individuals belonging to this group would employ non-obligatory vaccinations only in the case of direct danger of epidemic.

\section{Discussion}

A crucial factor that influences the decision on vaccination in the studied population is the knowledge of the subject. Persons not knowledgeable about vaccinations seldom decided to be vaccinated, e.g. against influenza. A similar relationship was observed by Dymek-Skoczyńska et al. in their studies, in which $29 \%$ of the subjects did not want to be inoculated with a vaccine against influenza because they had no knowledge of the effectiveness of vaccination [7].

A statistically significant relationship between the possessed knowledge on vaccination and the decision on vaccination in children was observed in the studied group. Knowledgeable parents more often declared readiness to have their children inoculated with obligatory and non-obligatory vaccines. A similar relationship was observed by Tarczoń et al. The studies showed that about $94 \%$ of parents who were aware of what diseases may be prevented by vaccination were in favour of obligatory and non-obligatory vaccinations of their children. Only $75 \%$ of the subjects without the knowledge of immunisation from a comparative group would support all prophylactic vaccinations [1].

There is justified concern that the low level of knowledge on vaccinations among parents may support the argumentation of anti-vaccination movements. The studies by Tarczon et al. demonstrated that $40 \%$ of the subjects thought pertussis is a disease no longer in existence, and 15\% of the subjects were also positive that measles does not occur in modern world [1]. Insufficient knowledge may result in the belief that vaccinations are not necessary, which in turn may lead to a decrease in vaccinations against these contagious diseases, and consequently a rise of their incidence in the future. It is also important that medical personnel propagate information about vaccinations and postvaccinal side effects, since a lack of such information may fossilise among parents false conceptions of undesired effects of vaccination, which in turn may enhance their fear of vaccination [8].

Physicians, an authority to most parents, and according to the studies by Mrożek-Budzyn et al., help to form parents' opinions about vaccinations, and thus they should keep encouraging parents to have their children vaccinated [9-11].

\section{Conclusions}

The level of the knowledge influences the decision on vaccination. Knowledgeable persons more often have their children and themselves obligatorily and non-obligatorily vaccinated. Not knowledgeable per- sons are less interested in regularity of vaccinations in accordance with the schedule. Education conducted by qualified medical personnel plays an important role in propagating knowledge of preventive vaccinations.

\section{Conflict of interest}

The authors declare no conflict of interest.

\section{References}

1. Tarczoń I, Domaradzka E, Czajka H. Co na temat szczepień ochronnych wiedzą rodzice i pracownicy ochrony zdrowia? Prz Lek 2009; 66: 27-33.

2. Yarwood J, Noakes K, Kennedy D, et al. Tracking mothers attitudes to childhood immunization 1991-2001. Vaccine 2005; 23: 5670-87.

3. Rogalska J, Agustynowicz E, Gzyl A, et al. Postawy rodziców wobec szczepień ochronnych w Polsce. Prz Epidemiol 2010; 64: 91-7.

4. Hubicki L, Czech E, Kowalska M, et al. Szczepienia ochronne dzieci $\mathrm{w}$ rodzinach o różnym stanie społeczno-ekonomicznym w Bytomiu. Prz Epidemiol 2004; 58: 713-23.

5. Rogalska J, Agustynowicz E, Gzyl A, et al. Źródła informacji oraz wiedza rodziców na temat szczepień ochronnych w Polsce. Prz Epidemiol 2010; 64: 83-90.

6. Mrożek-Budzyn D. Przyczyny niskiego wykonawstwa i opóźnień w realizacji obowiązkowych szczepień dzieci. Metody badań. Prz Epidemiol 2001; 55: 343-53.

7. Dymek-Skoczyńska A, Stanisławska J, Drozd E, Talarska D. Szczepienia przeciw grypie u osób w wieku podeszłym - czynniki determinujące decyzję pacjentów. Now Lek 2012; 81: 21-5.

8. Łukomska A. Determinanty szczepień przeciwgrypowych wśród osób w starszym wieku. Gerontol Pol 2009; 17: 114-9.

9. Mrożek-Budzyn D, Kiełtyka A. Czynniki wpływające na poprawę realizacji szczepień obowiązkowych dzieci na terenie województwa małopolskiego według opinii rodziców. Prz Epidemiol 2007; 61: 143-51.

10. Allred N, Shaw K, Santibanez T, et al. Parental vaccine safety concerns: results from the National Immunization Survey, 2001-2002. Am J Prev Med 2005; 28: 221-4.

11. Gust D, Strine T, Maurice E, et al. Underimmunization among children: effects of vaccine safety concerns on immunization status. Pediatrics 2004; 114: 16-22.

\section{Address for correspondence:}

\section{Zofia Śliwińska}

Wielospecjalistyczny Publiczny

Zespół Opieki Zdrowotnej w Zgorzelcu

ul. Lubańska 11, Zgorzelec, Poland

E-mail: zosia.sliwinska@interia.pl 